\title{
What is Employee Empowerment and how is it a key factor in helping organizations becoming more effective?
}

Walid Aboubakr Abouzeid 


\section{Abstract:}

Employee engagement simply refers to a workplace approach designed to ensure that employees are committed to their organization's goals and values, motivated to contribute to organizational success, and are able at the same time to enhance their own sense of well-being.Employee engagement can also be defined as the extent to which employees feel passionate about their jobs, are committed to the organization, and put discretionary effort into their work.

Engaged employees look out for the needs of their coworkers and the overall enterprise, because they believe that they personally 'own' the result of their work and that of the organization. They know exactly how their work and effort contributes to the success of the organization.

Empowered employees are engaged employees. They have all of the tools they need to learn and develop themselves, connect with colleagues and others throughout the organization, make their own decisions, be leaders and contribute to the success of the business. In simple terms, empowerment is a key driver of engagement. 
الملخص عربي

تهدف هذه الدراسة لتعريف و تحديد مفهوم تمكين الموظفين، وتسعى إلى تحديد الممارسات التي التي

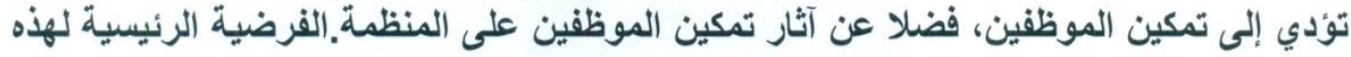

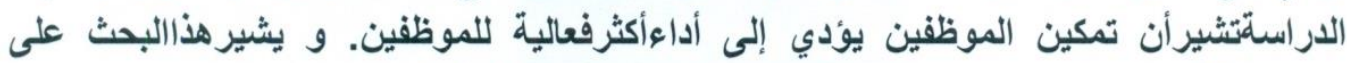
وجودعلاقة مباشرة بين تمكين الموظفين وزيادة إنتاجية المنظمة وفعاليتها.

إن تمكين الموظفين يلعب دورا كبيرا من حيث زيادة ربحية المؤسسة ،والحد من استقالة

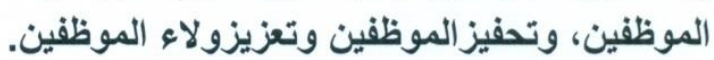

ويعتمد جمع البيانات في هذا البحث أساسا على استبيان مع موظفين من · r مؤسسة مختلفة.

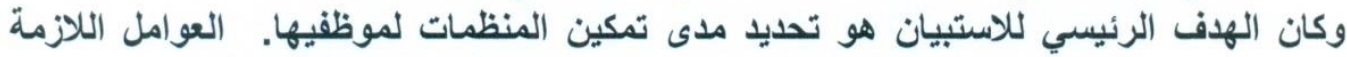

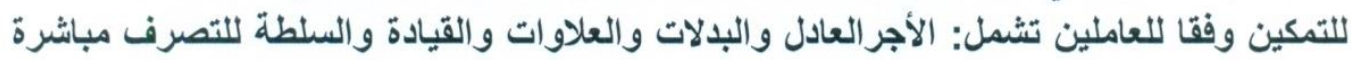
وفرص التنمية و التدريب والمشاركة في صنع القرار.

Pearson من أجل تحليل العلاقة بين تمكين الموظفين وفعالية المنظمة،قمنا باجراء اختبار Correlation Coefficient تمكين الموظفين وأداء|لمنظمة وفعاليتها.

وتشيرنتائج البحث بوضوح إلى وجودعلاقة قوية بين تمكين الموظفين وتحسن أداء المنظمات.

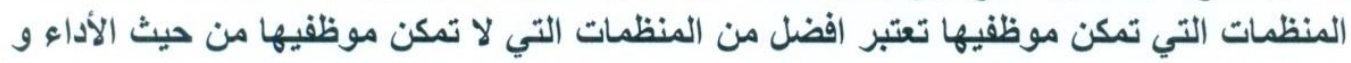
الانتاجية وارتفاع رضا العملاء والولاء،فضلا عن ولاءالموظفين مقارنة بالمنظمات التي لا تمكن

موظفيها.

التمكين يلعب دورا أساسيا في تعزيز تحفيزالموظفين نحو المهام التنظيمية. من خلال تقديرالموظفين لعملهم المنجز و إشر اكهم في صنع القرار،فإنهم سوف يصبحوا متحمسين لتحقيق أهداف المنظمة. وفي نهاية المطاف،يعتبرتمكين الموظفين مفتاح اساسي لنجاح المنظمات المنات. 


\section{Introduction:}

This study defines the concept of Employee empowerment, and attempts to identify the practices that result in empowering employees, as well as the effects of employee empowerment on the organization.

Employee empowerment, in simple terms, is an umbrella term that includes everything that enhances the capacity of people to make decisions and take actions that lead to desirable outcomes for the organization ${ }^{3}$.

Most, if not all, organizations understand the importance of empowering their employees in order to achieve improved business outcomes. Whether it's driving higher sales, increasing profit margins, enhancing customer satisfaction, reducing employee turnover or any other goal, businesses are looking for new approaches and tools to help employees do more to contribute to organizational success.

Research by the Gallup Organization suggests that organizations that actually empower their employees experience 50 percent higher customer loyalty. This reduces the resources needed to retain customers, in return, revenues and profits are more likely to grow faster.

Hypothesis:

The study's main hypothesis supports the fact the employee empowerment results in more effective employee performance. It is also believed that employee empowerment plays a great role in terms of increasing organization profitability, reducing company turnover, motivating employees and enhancing employee loyalty. Therefore the research's main objective is to identify the significance of employee empowerment on organization's effectiveness. 
This research attempts to prove that there is a direct relationship between employee empowerment and higher organization productivity \& effectiveness.

\section{Literature review:}

Empowered teams have been reported to accomplish tangible business results, for instance, FedEx was able to cut service errors by 13 percent, at Johnson \& Johnson, inventory levels were reduced by $\$ 6$ million a year. At Yum! Brands (owner of KFC, Pizza Hut, Long John Silver's, etc.), every employee is empowered to make decisions of up to $\$ 15$. Many instances have been reported where discounts of $\$ 10$ or more have been offered; resulting in customer appreciation\& satisfaction, higher loyalty, more repeat customers and word-of-mouth praise.

Empowered employees are more engaged - resulting in better retention and a higher quality of customer service. Empowered employees are also more motivated, leading to better performance and higher productivity. An empowered workforce is better aligned with an organization's business objectives, allowing companies to be smarter and more agile in an evershifting business landscape.

Empowerment can be viewed as a key performance indicator for the health and wellness of an organization's people strategy. Areas of talent management that include learning and development, performance management, succession planning and career management all can be used to promote a culture of employee empowerment.

Empowerment provides benefits to organizations and makes sense of belonging and pride in the workforce. In fact, it builds a Win - Win connection among organizations and employees; 
which is considered an ideal environment in numerous organizations and their employees.

Empowering can flourish virtual human capacities. Empowered employees focus their job and work-life with additional importance and this leads to constant progress in coordination and work procedures. Employees execute their finest novelties and thoughts with the sense of belonging, enthusiasm, and delight, in empowered organizations. Adding up, they work with a sense of responsibility and prefer benefits of the organization to theirs.

\section{Methodology \& data collection:}

This research's data collection primarily relies on a survey\& questionnaire that was conducted with employees from 20 different organizations, in Cairo, Egypt. The questionnaire's primary aim was to identify the extent to which organizations empower their employees.

The questionnaire examined the factors necessary for empowerment according to the employees and they included: fair pay, allowances and bonuses, leadership and authority to act directly without referring to the supervisor, appreciation, opportunities for development \& growth, valuing their suggestions, recognition, job stability, adequate training\& effective communication, task delegation and involvement in decision making. After the data collection, the companies were placed into two categories; low performance companies and high performance companies.This classification was based on their net income, market value, shareholder equity, book value, and profit margin.

The questionnaire also attempts to analyze and evaluate organizations' effectiveness by assessing employee turnover and percentage of employees achieving their monthly target. 
In order to analyze the relationship between employee empowerment and organization effectiveness, we will conduct the Pearson correlation coefficient test. This will help us to identify whether there is an association between employee empowerment and organization performance \& effectiveness.

The Pearson correlation coefficient is a measure of the strength of a linear association between two variables and is denoted by $r$.

The following table represents the results of the survey/questionnaire conducted:

\begin{tabular}{|l|c|c|}
\hline $\begin{array}{l}\text { Factors of employee } \\
\text { empowerment }\end{array}$ & $\begin{array}{c}\text { Low- } \\
\text { Performance } \\
\text { Company HR } \\
\text { System } \\
\text { Lowest 50\% }\end{array}$ & $\begin{array}{c}\text { High-Performance } \\
\text { Company HR System } \\
\text { Highest 50\% }\end{array}$ \\
\hline $\begin{array}{l}\text { Percentage of employees } \\
\text { with managerial authority }\end{array}$ & $9 \%$ & $\mathbf{7 4 \%}$ \\
\hline $\begin{array}{l}\text { Percentage of jobs filled } \\
\text { from within }\end{array}$ & $\mathbf{2 1 . 2 4 \%}$ & $\mathbf{6 7 . 4 2 \%}$ \\
\hline $\begin{array}{l}\text { Percentage of employees } \\
\text { receiving a regular } \\
\text { performance appraisal }\end{array}$ & 30 hours & $\mathbf{9 8 \%}$ \\
\hline $\begin{array}{l}\text { Average number of hours of } \\
\text { training/month for new } \\
\text { employees (employees hired } \\
\text { less than 1 year ago) }\end{array}$ & & $34 \%$ \\
\hline $\begin{array}{l}\text { Percentage of employees } \\
\text { promoted to managerial } \\
\text { positions annually }\end{array}$ & $8 \%$ & \\
\hline
\end{tabular}




\begin{tabular}{|l|c|c|}
\hline $\begin{array}{l}\text { Average number of hours of } \\
\text { training/month for } \\
\text { experienced employees }\end{array}$ & $\mathbf{6}$ hours & $\mathbf{4 3}$ hours \\
\hline $\begin{array}{l}\text { Percentage of employees } \\
\text { involved in board of } \\
\text { directors and top } \\
\text { management meetings }\end{array}$ & $\mathbf{4} \%$ & $\mathbf{2 6 \%}$ \\
\hline $\begin{array}{l}\text { Firm Performance } \\
\text { Percentage of Employee } \\
\text { turnover }\end{array}$ & $\mathbf{3 7 \%}$ & \\
\hline & & \\
\hline $\begin{array}{l}\text { Percentage of Employees } \\
\text { who achieve their monthly } \\
\text { target }\end{array}$ & $\mathbf{4 2 \%}$ & $\mathbf{8 9 \%}$ \\
\hline
\end{tabular}

\section{Research Findings:}

After the Pearson Correlation Coefficient test was conducted, we were able to observe the following:

Pearson Correlation Formula:

$$
r=\frac{\sum X Y-\frac{\left(\sum X\right)\left(\sum Y\right)}{n}}{\sqrt{\left(\sum X^{2}-\frac{\left(\sum X\right)^{2}}{n}\right)\left(\sum Y^{2}-\frac{\left(\sum Y\right)^{2}}{n}\right)}}
$$

The following table includes a sample obtained from the previous table for the high performance companies: 
$r^{2}=1$

$r=-1$

The results above indicates a very strong and perfect correlation/ assosciation between the two variables, in other words, there is a very strong relationship between empowering employees and better organizational effectiveness \& performance.

In order to support the research's hypothesis, the coefficent of determination $r^{2}$ was also calculated.

Coefficent of Determination value interpretation $\left(r^{2}\right)$ :

\begin{tabular}{|c|c|}
\hline Value & $\begin{array}{c}\text { Strength of } \\
\text { association } \\
\text { No correlation }\end{array}$ \\
\hline$r^{2}=0$ & $\begin{array}{c}\text { Very weak } \\
\text { correlation } \\
\text { Weak correlation }\end{array}$ \\
\hline $0<r^{2}<0.25$ & $\begin{array}{c}\text { Moderate } \\
\text { correlation }\end{array}$ \\
\hline $0.25 \leq r^{2}<0.50$ & $\begin{array}{c}\text { Strong correlation } \\
\text { Very strong } \\
\text { correlation }\end{array}$ \\
\hline $0.75 \leq r^{2}<0.75<0.90$ & Perfect correlation \\
\hline $0.90 \leq r^{2}<1$ & \\
\hline$r^{2}=1$ &
\end{tabular}

According to the previous table, the coefficient of determination indicates a perfect correlation between employee empowerment and improved organization performance.

The correlation test was also conducted on a sample from the low performance companies, and the following results were obtained: 


\begin{tabular}{|c|c|}
\hline $\begin{array}{c}\text { Variable X } \\
\text { (Employee } \\
\text { empowerment } \\
\text { factors) }\end{array}$ & $\begin{array}{c}\text { Variable Y } \\
\text { (organization } \\
\text { effectiveness and } \\
\text { performance } \\
\text { indicators) }\end{array}$ \\
\hline $\begin{array}{c}0.09(9 \%) \\
\text { Percentage of } \\
\text { Employees with } \\
\text { Managerial } \\
\text { Authority }\end{array}$ & $\begin{array}{c}0.37(37 \%) \\
\text { Percentage of } \\
\text { Employee } \\
\text { turnover }\end{array}$ \\
$\begin{array}{c}0.04(4 \%) \\
\text { Percentage of } \\
\text { employees } \\
\text { involved in BOD } \\
\text { and top }\end{array}$ & $\begin{array}{c}0.42(42 \%) \\
\text { Percentage of } \\
\text { employees } \\
\text { achieving their } \\
\text { monagement } \\
\text { meetings }\end{array}$ \\
\hline
\end{tabular}

Linear Regression

$y=a x+b$

$a=-1$

$b=0.46$

$r^{2}=1$

$r=-1$

The results of this sample also indicate a perfect correlation between the two variables; employee empowerment factors and organization effectiveness. 


\section{Conclusion:}

According to the questionnaire and the results of the correlation test conducted within this study, it can be stated that the research's hypothesis is correct and is supported by statistical evidence.

The research findings clearly indicate a strong relationship and association between employee empowerment and improved organizational performance. Organizations that actually empower their employees experience higher productivity, lower turnover rates, higher customer satisfaction \& loyalty as well as employee loyalty.

Although correlation between two variables does not necessarily mean that one variable causes the other, it does however in this research highlight the association between implementing employee empowerment factors and improved organizational performance.

Empowerment plays an essential part in enhancing employee motivation towards organizational tasks. By appreciating the employees for their work done and involving them in decision making, they will become highly motivated and enthusiastic to achieve the organization's goals and objectives. Eventually, employee empowerment is thus considered as a key for organizational success. 


\section{References}

1. Yazdani, B. O., Yaghoubi, N. M., \& Giri, E. S., (2011). Factors affecting the Empowerment of Employees. European Journal of Social Sciences, 20 (2), 267-274.

2. Forbes.com (2012): 'Why Employee Engagement? http://www.forbes.com/sites/kevinkruse/2012/09/04/whyemployee-engagement/

3. Mathematics for the international student: mathematics studies SLCoad, Mal, Glen Whiffen, John Owen, Robert Haese, Sandra Haese, and Mark Bruce. "Two Variable Statistics." Mathematics. Adelaide Airport: Raskar Nominees Pty, 2004. 572-600. Print.

4. Chowdhury, M. S., (2007). Enhancing Motivation and Work Performance of the Salespeople: The Impact of Supervisors' Behavior. African Journal of Business Management, 1 (9), 238-243.

5. Dessler, Gary, and Akram AL Ariss.Human Resources Management- Arab World Edition. N.p.: Pearson Education, n.d. Print. 